\title{
Christine Brooke-Rose: Motes, Beams and The Horse's Mouth
}

\section{Glyn White}

The founding of the Christine Brooke-Rose Society and its inaugural event prompted me to revisit my history with the author with whom I was fortunate enough to correspond during the last decade of her life. Our correspondence ran alongside my completing a $\mathrm{PhD}$, gaining full-time employment as an academic, getting married, becoming a father and publishing a monograph and a number of articles, including over twenty-five thousand words of criticism on Brooke-Rose's work. During the same time Brooke-Rose was working on her late novels and her last book of criticism, contending with accumulating illness and disability and the approach of the ultimate, end of. Our contact focused on Thru, the novel that sets itself at the intersection of the critical and the creative in an academic environment and a text she herself was already retrospectively revisiting at this time in the article that became chapter five of Invisible Author: Last Essays. ${ }^{1}$ This essay draws on that correspondence to consider Brooke-Rose's relationship to academic criticism as a critic and novelist, the ways in which those overlapping identities affected each other and, with reference to Thru, to suggest how her work in both fields offers significant insights and opportunities relevant to both contemporary critical thought and literary practice.

\section{The Horse's Mouth}

I met Christine Brooke-Rose once - and only briefly - in late 1995 when she came to the University of East Anglia in Norwich, where I was studying, and gave a paper on the first twenty-one pages of Thru, exposing aspects of it that hadn't been picked up by critics since its publication twenty years previously. The paper had been written for a conference elsewhere and, as Brooke-Rose indicates in the footnote on page 63 of Invisible Author, she was on her way back to France when she gave it. This second airing was thus a somewhat impromptu event, set up by Professor Lorna Sage. PhD students and staff filled a medium-sized common room, seated in comfortable chairs around the edge of the space. Photocopies of the first twenty-one pages of Thru were distributed for us to pore over and follow the commentary. Time for questions came.

Christine Brooke-Rose was lean and grey and very sharp. She wasn't conceding anything, even to Lorna. When the floor was opened, an ambitious member of staff asked a look-at-me question that was very general and coolly received. 
Silence threatened.

I asked a question about the upside down text on page twenty-seven, thereby showing that there was a person in the room who had read the book (in fact I still had the UEA library copy out). This did me some good with Lorna, but most importantly got an engaged answer from Christine that really helped my research; Thru would become central to my thesis. Later, when I'd made some headway with the $\mathrm{PhD}$, Lorna encouraged me to contact Christine and passed on her Avignon address.

I felt obliged to write even though I was skeptical about whether much would come of it as, ideologically, I was convinced that authors were dead. My letter asked Professor Christine Brooke-Rose if she would be kind enough to look at a section of the chapter of my thesis that discussed Thru, and, if so, she was invited to 'please get in touch by any means available [since] I would be delighted to hear from you'. ${ }^{2}$ About a week later, as I walked into my lodgings, my landlord left the telephone receiver on the table with the words, 'It's for you'. It was Christine Brooke-Rose asking who I was, what I was doing, what I was writing. It was rather like an on-thespot viva. The outcome of our discussion was that, yes, I could send her the chapter section which we corresponded about at some length (something I will return to below).

Later in our correspondence we discussed an article I was writing about Thru that was published in Poetics Today in 2002 and, several years after completing my thesis, I was able to send her the monograph arising from it (2005) which contains a substantial chapter on Thru independent of the Poetics Today piece. ${ }^{3}$ In the covering letter accompanying the book I claimed it was the largest chapter, which was true in terms of wordcount, but she pointed out that the following chapter had more pages (simply due to the illustrations included). ${ }^{4}$ There was no getting away with anything with Christine. Over the telephone, she listed some minor things for me to correct for the second edition and, most exasperatingly, suggested a shorter, better title for the book. These high standards made it all the more rewarding when she was kind enough to say she liked my work or countenanced a particular reading. Our initial run of correspondence closed with 'You have got as close as can be to the text', something I take to be high praise. ${ }^{5}$

I have used the term 'the horse's mouth' in the title and subtitle above, not for the occasional bite or to suggest that my contribution to Brooke-Rose studies is any more authoritative because of these personal links, but because this was the term 
Christine used for her authorial feedback on what I had written about her work. To hear an opinion from the horse's mouth is a twentieth-century horseracing metaphor, indicating the reliability of a tip about the outcome of a race, but also (since it involves a talking horse) suggesting that it is too good to be true. Brooke-Rose's choice of it is particularly apt, for she was well aware that the horse's opinion is not the same as the outcome of the race, even if it is uniquely well-informed. In using it, she was expressing her own ambivalence about what the New Critics called the intentional fallacy, and it was clear she was suspicious of my reasons for seeking contact in the first place:

You may have expected the author to explain all, and be disappointed. But you should know my views, since you quote so much of my criticism. I am in principle against Author's Intention and the present fashion for students to interview them etc. It not only includes laziness, but, more seriously, if the author fails in her intention it has no value at all. Thus I am all for Readers' Interpretations. Nevertheless (and of course) this can let loose all sorts of aberrations. ${ }^{6}$

The fact was, rather than send the whole of my chapter on Thru for approval subjecting it to a potentially devastating authorial review - I had specifically sent material which engaged with the aspects of this novel that I was struggling with.

\section{Thru's Contentious Arc-Icons}

The problematic pages were the arc-icons on pages 37 and 156 of the original edition, which were then quite disproportionately prominent in critical accounts of both Thru and the work of Christine Brooke-Rose. ${ }^{7}$ The first was reproduced in Morton Levitt's Dictionary of Literary Biography entry on Brooke-Rose and Brian McHale's important study Postmodernist Fiction reproduced the second icon. ${ }^{8}$ Heather Reyes' 1998 thesis on Brooke-Rose had argued how atypical these pages were, and how this emphasis distracted from a focused interpretation of Brooke-Rose's work. ${ }^{9}$ My thesis's focus on the visual aspects of fiction did not allow me to sideline these icons; I had to make sense of them. I understood that the shaping of text in Thru came from the narrational context and I was reaching for explanations beyond those of McHale whose main objective was to show the turn from modernist focus on epistemology to 
postmodern concern with literary ontology. My draft had the temerity to see a leaf shape (a visual interpretation with no textual justification) and link it to a Chomskyean tree diagram (something at least referred to in the text), but these proved to be aberrations. Brooke-Rose insisted they were meant to represent arc-lamps (a powerful type of street lamp), though in a Freudian typographic slip they also became 'arc-lmps'. 10

To rein me in Brooke-Rose cited two published examples of overinterpretation of her work that had proven irksome. Damian Grant's assertion that the triangle on page 1 of Thru was James Joyce's ALP triangle and, quite topically for 2016, Richard Martin's anachronistic interpretation of the phrase 'Shall we ever make Europe' in Amalgamemnon (1984) as relating to Britain's joining of the European Union as opposed to the creation of 'a valid union'. ${ }^{11}$ The general upshot of both of her examples was: ' $N$ 'allez pas cherchez midi à quatorze heures'. ${ }^{12}$ When it came to what she called the arc-lamps, Brooke-Rose was unhappy with McHale's interpretation of them as resembling a lecture theatre, particularly because, as in the Martin example, she'd attempted to correct his interpretation before publication:

I saw McHale's pages before they were printed and wrote to him that the design couldn't possibly be students in an amphitheatre since that image doesn't occur till later. And told him Author's Intention. Which he chose to disregard or place in a dismissive footnote. Fine. ${ }^{13}$

In fact, McHale includes a long endnote in Postmodernist Fiction that is fairly evenhanded. He explains that:

The word-pattern of broken arches occurs only twice, here on p. 156 and earlier, in a slightly different version, on p. 37 , but its signification is multiple each time. It seems to refer not only to a lecture-hall, but also to patterns of light cast by streetlights on a wide boulevard... as well as to a more abstract 'object' of representation, discussed below. I wish to thank Christine Brooke-Rose herself for reminding me of the proliferation and slippages of meaning among the concrete prose passages of Thru. ${ }^{14}$ Essentially, this is an agreement to a difference of opinion, though McHale doesn't indicate which of the possibilities Brooke-Rose preferred. 
The difficulty of interpreting Thru is caused by what Brooke-Rose called its 'absolutely objective narration', where the narration comes from within the thoughts of the character(s) with no introduction or framing for the reader to locate themselves, or even to identify shifts between characters. ${ }^{15}$ The motivation for the extraordinary shaping of the typography here and elsewhere in Thru comes from within the minds of the perceiving consciousness which is being read, but a lot of the reader's interpretation depends on which phrases, scenes or observations they take to be significant, not just within but around the 'arc-icons'. The last words on the page preceding the first of these icons include a list of names followed by: 'shouting at faculty meetings where faculties never meet even on an imagined curve or even as an audiovisual illusion of a coherent structure diminishing in size' (36). The content of the first icon appears to be dialogue from a meeting, 'canyons of tall speeches of protest' about 'the idiotic affair', punning on a relationship and ending in 'Order, [o]rder' with both pendant to a single 'o' that elsewhere in the text symbolises 'the Other', not order. On the following the page (38) the setting is clearly an academic meeting with 'colleagues', 'agenda', and issues over recruitment policy being discussed.

The second arc-icon comes over one hundred pages later, only seven from the end, and emerges out of a creative writing class voting on whether or not to kill Larissa, a character in their joint narrative, and possibly also their creator and/or their tutor's ex-wife: 'I vote we vote first whether to vote for those against abstinence refusal of representation with a show of hands in the secret ballet of the I where faculties never meet even on an imagined curve as illusion of a coherent structure diminishing in size' (155). The following arc-icon has some of the same text as the first but is more clearly a classroom setting (from a lecturer's point of view) when it includes: 'the peripatetic fallacy of the rectangular room into which you enter and walk up and down [and are forced to read upwards and downwards] before a sea of floating faces that stare into spacetime or utter (rubbish) ances and bend their blonde black heads to write down $\mathrm{V}=\mathrm{F}$ ' (156). Again the text on the page ends in a call for 'Order, [o]rder', but a decision is not reached about Larissa's fate. She appears later, under her surname Toren, in the subsequent listing of names and grades (pp. 159-163, attributed to the student body on p. 163) scoring an ' $x$ '. This may seem like a fail grade but it is linked to the chiasmus, used emphatically in the novel since the first page and linked to Griemas's 'logical rectangle of contraries and contradictories', 
which is seen as comically reductive and specifically parodied in Thru, but which also becomes a sign of the 'interchangeability of narrators'. ${ }^{16}$ In fact, a reference to the four-cornered diagram introduces the last list of grades:

\author{
superimposing unlimited antisystems \\ unto sixteen times sixteen time sixteen $^{\mathrm{n}}$ \\ possible balanced relationships in \\ endless permutations \\ represented in a hidden representation \\ inside a representation alphabetically \\ marked in columns that support the \\ proepigrammed linguistic edifice \\ of marked and un-re-marked \\ sem(id)Iotic \\ irrecoverable \\ narrators \\ gone (Thru, 159)
}

As Judy Little succinctly puts it in The Experimental Self: 'Christine Brooke-Rose deconstructs the presumptions of agency and authorship as her puzzled characters in Thru try to ward off the comic frustration of having written each other'. ${ }^{17}$ I'll say more about another aspect of the chiasmus in the novel later but, while we are here, we can look back at the above quotation and note that (if it is reproduced correctly) the first letters of the lines spell a word that can be read vertically (i.e. 'superimposing'). This was one of the elements of the text Brooke-Rose revealed in her twentieth anniversary paper on Thru: the existence of vertical text, superimposed on the pages and almost invisibly governing layout. What I hope to have established with the foregoing is that by the end of Thru we still cannot establish a narratorial hierarchy and the text contains occulted elements dependent on its visual presentation. $^{18}$

McHale's decision that the arc-icon represents a lecture theatre, in the latter instance which he quotes, is thus a plausible mimetic explanation but is also, as Brooke-Rose complained, reductive. In the context of a survey of postmodernist fiction there is not room for all possible interpretations to be entertained, as McHale's 
endnote admits, but in any individual reading such limiting of interpretative possibilities is also inevitable. It is too difficult to continue reading if the reader does not limit possibilities, just as the writer only represents certain aspects of the world they generate. Brooke-Rose is aware of this: 'The moment we utter a sentence, we're leaving out a lot. I mean this idea... that we are just taking bits and pieces of reality, which is what language does automatically. We're doing a découpage of reality and all the more so when we write a novel or a poem or anything else'. ${ }^{19}$ But as the author and as 'first reader', ${ }^{20}$ Brooke-Rose cannot help but see, and thus wish to privilege, her intent:

I can only repeat Author's Intention, which you're also free to say doesn't come off and anything you like. As I worked so hard at them, both writing and typing them, I do remember what I intended: the couple have parked and got out of the car, in a long street with arc-lamps that get smaller and smaller in the distance. I don't see what's so difficult about that image AS SUCH, though you're free to say that arc-lamps don't look like that or the circumstances or context aren't clear enough. Armel (if it's him, and it is in my head) who's going to the girl's flat (and that scene is later told by Mira as 'Ruth' in a Creative W. class), is standing looking at the arc-lamps and thinking of a faculty meeting quarrel, o $\quad r$ probably of a 'typical' quarrel, not a specific one. This typical quarrel in his head is the only indication that it's him looking at the arc-lamps and not the girl. The superimposition of that reconstruction on the arc-lamps IS perhaps difficult, but once grasped there's plenty in the text to support it, only I'm still too unwell to look for it. I'd much rather you stuck to this interpretation and maybe explained why it doesn't come off (and I agree the print in the arc-lamps is very hard to read, and moves in the wrong direction in some, etc, I was after all experimenting, and that is what [typo]graphic[ally innovative] novels do, and maybe failing) than introduce all those alternative readings that blur the final effect for the reader. $^{21}$

The best interpretation is therefore authorial intention, and though alternatives are still in theory permitted, they may negatively affect the intended effect. My response letter 
thanking the author for all of this input was followed by a 'ps' from her, showing that in spite of her ill health (mentioned in the quotation above) she was still gnawing away at some of the issues and contradictions raised. In particular Brooke-Rose noted that, in first letter, there was:

an element of insisting both that the Author's Intention isn't valid AND that my intention was arc-lamps. It's due to my being two people. The Theorist is Reader-oriented (within reason! having gone thru every position from Oxford's 'first establish the author's intention' school of the late forties to 'text only' etc etc). The Author gets quite peeved (a manner of speaking) at 'aberrant' readings.

But you've grasped the main point. I'll add: the general rule, when interpreting, is to ask yourself; how relevant, and how enriching? ${ }^{22}$

It is possible to see these opinions in her contribution to Interpretation and OverInterpretation (1979), and in various places in Invisible Author. ${ }^{23}$ Brooke-Rose is conscious of 'the author's vanity': 'I'm always delighted when a critic reads something I hadn't thought of, if it enriches (i.e. I feel clever to have 'perhaps' meant that). But slightly 'peeved' if it impoverishes'. ${ }^{24}$ This reiterated self-awareness, was the platform for an acceptance that McHale's position was valid:

McHale's 'amphitheatre' is, as you point out, relevant to the context, and only 'mistaken' re. Author's Intention (which doesn't count!), i.e. Armel COULD be superimposing amphitheatre and faculty meeting in his head at this point (ahead of the later metaphor of the amphibian-theatre). That's why I merely pointed out my intention to him in my letter but didn't pursue it. He's entitled to the interpretation, though it leaves Armel in the street thinking of TWO other things, indeed, no longer in the street at all, and possibly no longer Armel (vision detached from context could be new character). Whereas in my Intention he's still there in the street and the lamps make him think of faculty meetings (which 'never meet'). I.e. it's 'motivated'... 25 
Part of the difference in opinion here is clearly because Brooke-Rose's focus is on the earlier example of the icon while McHale's is on the latter. Though I wasn't able to straighten this out at the time, it is clear that both readings can co-exist within the novel tied to separate icons. The question begged, however, is, even if we focus on the first of these icons, can it be reduced to one intention when other possible readings proliferate? The first icon follows on from a journey taken by the focalising consciousness of the passage (in Brooke-Rose's intention Armel) and a female partner, but it isn't clear whether the character in the street seeing the arc-lamps (arcing towards each other but never meeting) and reading them as a metaphor for faculty meetings where there is no agreement OR is now in the faculty meeting thinking of the arc-lamps as a metaphor. Brooke-Rose's absolutely objective narration is sufficiently ambivalent for both to be possible, and both are enriching.

\section{'Building Our House on Quicksands'}

The ambivalence between readings allowed by this novel's technique gives rise to a peculiar effect, specifically the feeling that, as it says in the first arc-icon text, 'we're building our house on quicksands' (36). This is an extension of the parable of the wise and foolish builders in the New Testament, in which the wise builder builds on rock, the foolish builder on sand. ${ }^{26}$ As readers we're not grounded in the way we feel we ought to be when reading Thru: our hypotheses about who is narrating, about where they are and the nature of their relationships with other characters (who might also be narrators or co-narrators) remain deeply unstable throughout, as indicated above. This instability is the defining factor of this novel, and therefore Thru has:

the full postmodernist repertoire of destabilising strategies, including selfcontradiction; the placing of episodes or descriptions 'under erasure'; socalled 'strange loops'; trompe-l'oeil effects, such as 'demoting' an event, character, or object to a lower narrative level or, conversely, 'promoting' one to a higher level; mise en abîme; irresolution or hesitation between mutually exclusive alternative scenarios; and so on. ...Thru, in other words, is a text of radical ontological hesitation: a paradigmatic postmodern novel. ${ }^{27}$ 
As I argued in Poetics Today (2002), we must be careful not to panic when we observe all these techniques, as they do not make this text unreadable or act as devices capable of trapping the reader. ${ }^{28}$ While the critic might potentially end up in over their head in this quicksand-like instability and embedded within numerous theoretical contradictions, readers have to read and require quicksand-crossing techniques. Reading means making a découpage of the text as indicated above, but also putting a couple of metaphorical planks down to walk across and, for future use, retrieving those planks if at all possible. Thru's technique of undercutting anything we might think we have established as solid might mean the planks we have used turn out not to exist, but as readers we have still crossed to the other side of the quicksand, even if we are only finding ourselves in more of it. The panicky feelings of the characters ('we're building our house on quicksands'), and their penchant for grading the performance of other characters and their writing, including 'the placing of episodes or descriptions 'under erasure', the 'demoting' of an event, character, or object to a lower narrative level or, conversely, the 'promoting' of one to a higher level, and the irresolution or hesitation between mutually exclusive alternative scenarios', are - as in the final lines of the arc-icons - attempts to impose order. ${ }^{29}$ However, these attempts are enacted from instability (quicksand) and therefore are destined to fail, for example the cancellation of a scene from the class's narrative might invalidate it but cannot wipe it from the memory of the reader or the page. Therefore, the internal resistance by the characters to the 'quicksand' of instability can be linked to another biblical reference in Thru, that of the parable of the mote and the beam: 'And why beholdest thou the mote that is in thy brother's eye, but considerest not the beam that is in thine own eye?'. ${ }^{30}$ The terms 'mote' and 'beam', which other translations substitute with 'speck' and 'log', 'splinter' and 'plank', are used recurrently in the acrostic layout on page six of Thru (where words can be read vertically and horizontally, with some letters doing double duty). That page is themed by eye motifs, so that King Lear and Georges Bataille are invoked alongside Derrida's deconstruction of Freud..$^{31}$ The presence of 'mote' and 'beam' in this context is interesting. The parable illustrates the proverb contained in the previous two verses: 'Judge not that ye be not judged. For with what judgement ye judge shall ye be judged: and with what measure ye mete, it shall be measured unto you' ${ }^{32} \mathrm{I}$ believe there is a link here between the quicksand that the novel forces us to build upon and our consequent judgement of the builder. We need to remove the critical 
beam from our eye in order to critique any mote we perceive to be floating in the atmosphere of the text. This is a lesson against the hypocrisy of judging while blinded, and of insisting upon things being a certain way. Another recurrent motif in the novel is that of Wallace Stevens' poem 'The Man with Blue Guitar' (1937), whose listeners complain 'You do not play things as they are'. Fiction may represent, but 'Things as they are are changed upon the blue guitar'. ${ }^{33}$ Fiction cannot be reality, but nor can it completely cut loose from it because language has a built in referential function. ${ }^{34}$ Furthermore, neither reader nor critic can compel a text to conform to their expectations. Fiction is thus not obliged to build its house on rock:

the postmodern novel is the novel in rebellion against two major laws of philosophic logic. The first is the law of non-contradiction which says that an argument is flawed if it contradicts itself. The second is the law of cause and effect which organises not only philosophical argument but the events of a novel, the relation of the novel to criticism, the relations between modernism and postmodernism, or personal and historical experience in general, as a linear sequence. The novel is superior to philosophy exactly because it is not constrained by such laws. It has acquired an epistemological importance in contemporary culture because it has always had the power to question the certainties of traditional philosophic argument, to be dialectical, to be complex. ${ }^{35}$

In other words, fiction can build itself on sand, even on quicksand as in Thru, and endure.

\section{Author and Critic $=$ Horse and Rider, but which rides the other?}

The mutability of possible interpretations of the arc-icon pages is instructive, perhaps especially as possible interpretations proliferated the more both author and critic sought to pin it down. Before I had a chance to respond to the author's second letter on the subject a PPS of a third letter followed, as Brooke-Rose realised she hadn't included the key point:

although I may (or may not) have been aware of how 'unrealistic' the design of the arclamps had become, the important point, for me, was the metaphor: the arclamps don't meet (this is in the text), because they 
alternate on opposite sides; nor do the speeches of the people at the meeting, also on opposite sides (implicit only, but what they say is in the text inside the design). It's a functional metaphor, a type Donne was fond of, which likens two things in virtue of what they do (or in this case don't do), rather than what they look like, which is the more usual type. ${ }^{36}$

Finally, the whole discussion appears to be closed off with:

End of Horse's Mouth on Arclamps. Except that it's not just the Author's Intention, it's IN THE TEXT! If you use it, please make this clear, and settle these absurd mis-readings once and for all. It's also a good guide to other puzzles maybe. Although I don't always remember, and can't always explain (and shouldn't!), I know there's nearly always a reason (good or bad) for anything I do (and good to me or course, otherwise I wouldn't do it). So read the text all round, closely. ${ }^{37}$

When the author is also a critic, they know how a critical reading should be conducted. Authorial knowledge is almost a handicap. Certainly the assumption that critical reading will (this time) end up in agreement with authorial intention seems to have set some alarm bells ringing for the critic and the letter ends with another paragraph that is technically a PPPS:

I see on checking that I didn't do this myself! On p. 36 (opposite the arclamps) the provisional consciousness is no longer in the street (unless he's been thinking of classes etc since SILVER GRINS on p. 31) but very much with teaching and meetings ('musical chairs bottom-shaped with liftable flaps...') So my last letter was misleading, I was writing from fallible memory. All the more reason for this letter, the point of which is still true but perhaps should be inverted: 'shouting at faculty meetings where faculties never meet even on an imagined curve or even as an audiovisual illusion of a coherent structure diminishing in size', i.e. we're at the faculty meeting, remembering the arclamps! Easier in a way, except that the arclamps have not been mentioned before! This is a good lesson 
in the obligation to check and not trust one's own memory, even for the author. But that's what close reading means. ${ }^{38}$

This is wonderful advice for the $\mathrm{PhD}$ researcher, both in the practice of their research and the weight they may - or may not - give to authorial statements from the horse's mouth. But, with a little more close reading, even this conclusion could be revisited. Of course, we must remember we are building our house on quicksands because the phrases we notice and pick out (our temporary planks of meaning) do not appear to stay solid, but Brooke-Rose's ultimate interpretation of the first arc-icon is eminently supportable. On page 17 arc lamps are mentioned, with the focalising character:

now standing in

the wide street recumbent under great curved beams of pale light equispaced but staggered each to the other laterally, the quarter arches never meeting even on an imagined curve except quite distantly along the can yon of tall blocks all asleep all dreaming along the boulevard as they diminish in size quite distantly.

On page 19 the canyons mentioned in the arc-icon are emphasised in a page of acrostic text. On page 26 Armel writes: 'Larissa my love. This is going to be a disconnected letter as I am writing it during a faculty meeting' but, typically in Thru, we don't get true epistolary form but instead read what he thinks while he is writing. ${ }^{39}$ Then, on page 30 when we are in the creative writing group composing the group narrative - or flashing back to it in their teacher's mind - we note that: 'The writer is the reader and the reader is the writer'.

Reversibility is possible at virtually every turn, and questions about who is narrating (the 'Who Speaks' from Barthes) are a constant refrain, but the thread of ideas that link arc-lamps and faculty meeting are clearly present. What dissolves is certainty about who is focalising and what their perspective is (are they remembering the faculty meeting or remembering the street with the arc-lamps?). That the novel could apparently catch its own author out on such details certainly illustrates its instability, but it also points to its richness. 
While writing my thesis, I attended an event in London where I was introduced to an American $\mathrm{PhD}$ candidate who I soon learned was also working on Brooke-Rose. Anyone who has done a $\mathrm{PhD}$ will know the sort of questions that immediately follow:

Which novels are you studying?

Mostly Thru. [uh oh, me too]

When are you submitting?

In month x. [uh oh, sooner than me]

But the panic didn't last long. The more we talked, the more it became clear that there would be virtually no overlap between our theses because of the richness of this text. My interlocutor, Brad Buchanan, was focusing on Thru's mythological references, while my work focused on the visual aspects of Thru and how they grounded the floating text in its physical manifestation. If Thru is a text that excites you, it is possible, even probable, that you have an entirely other take on it.

Brooke-Rose should be recognised as a uniquely rich critic and novelist working at the highest intellectual level in both fields, but she seems to have become increasingly aware, as retirement, illness and age limited her capacity to work in either field, that her twin legacies are almost mutually exclusive. There is no difficulty at all in our celebrating both the novels and the critical work, but there is considerable practical difficulty in writing about them side by side. Instead, one uses the criticism to interpret the novels or, perhaps, the novels to prove the criticism. It's one of those difficult binaries where the two elements exist in an implicitly hierarchical relationship of novelist/critic, or possibly critic/experimental novelist. Thru, acknowledged as her favourite novel, is the novel where the lines between critic and author are most blurred. ${ }^{40}$ She claims that 'writing it resolved my writer/critic conflict', but the long hiatus in her publishing of fiction afterwards points to either the productive nature of that inner conflict or the damage Thru's reception did to her career as a writer of fiction. ${ }^{41}$

In many ways her later critical works are metacriticism, commenting on the state of the discipline, noting - and protesting - its quirks and fashions. Brooke-Rose critiques content-based criticism predicated on summary. ${ }^{42}$ In her shorthand for criticism 'the how and the what' comes first. ${ }^{43}$ In Invisible Author Brooke-Rose argues for the inadequacy of the 'narrator' to cover all eventualities, and for the radical nature of her key innovation (or lipogram or constraint), only lately identified: 
'a refusal of the narrative past tense, replaced by a simultaneous present tense' that she picked up from Robbe-Grillet's La Jalousie and ran with thereafter. ${ }^{44}$ The point is well made and is something Brooke-Rose was so passionate about she was later seeking to create an endowment fund in her name that would fund further investigation in this area. ${ }^{45}$ To the best of my knowledge, supported by an internet search, this did not ultimately happen.

Some might argue that the death of the author, figurative or literal, invalidates the setting of an agenda through which their (or all) novels are evaluated. The problems and frustrations for Brooke-Rose were that she was in many ways ideally equipped to pursue the topic, but was equally disqualified from pursuing it because it could not be anything other than an investigation into her own work. In Invisible Author she notes 'the current double paradox, that despite the long taboo on author intention..., writers are constantly invited to talk about their work (first paradox), though the taboo survives that they are not supposed to write about it (second paradox)' ${ }^{46}$ The paradox can be seen today in the insertion of brief interviews with authors into to the back of their bestselling books, in lieu of the prefaces and forewords of earlier eras.

Yet not all of her latter critical work is self-referential. Brooke-Rose conducts a fascinating analysis of House of Leaves by Mark Z. Danielewski in the dual Coda to Invisible Author. Her analysis dissects (or perhaps bisects) the novel mainly in terms of 'how' it relates to the concept of present narration outlined above. In particular, Brooke-Rose notes the traction Danielewski gets out of juxtaposing a third person present tense narrative (the extensive but impossible description of a video by a blind man) with a colloquial present tense narration by the hedonistic Johnny Truant. No matter how technically interesting the 'how', the critic finds that other practitioners use it (in this case particularly effectively) to foreground a 'what' that fascinates. A brief example from one of Truant's extended footnotes should make the point of how the present can deliver within the gothic genre:

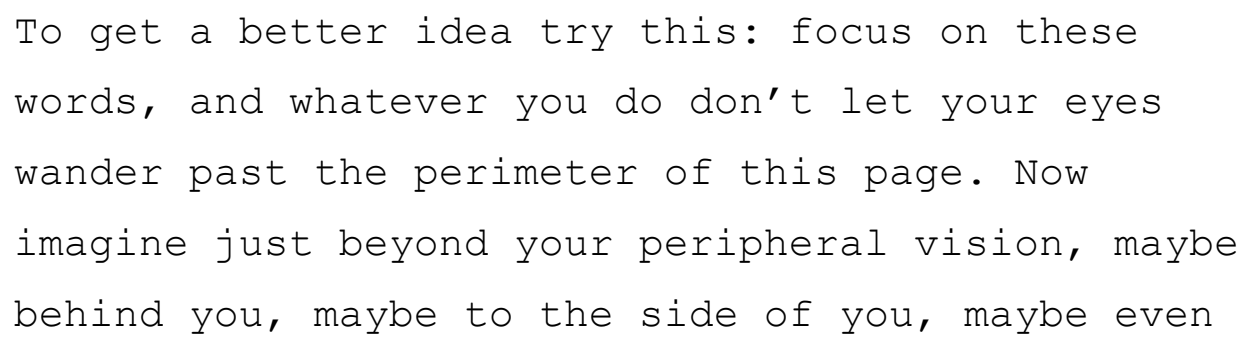




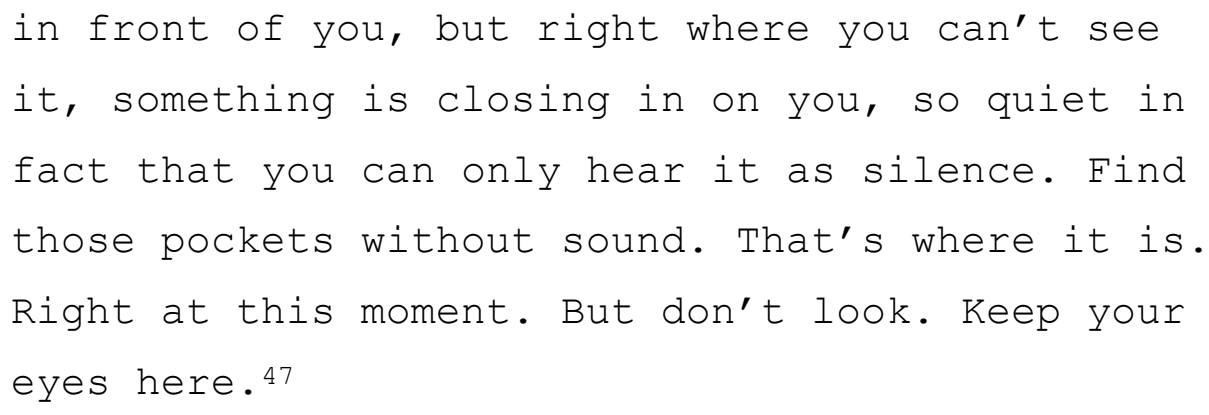

The form (including different typefaces for different narrators) does an awful lot of work in framing and shaping House of Leaves, but makes it appear uncanny rather than calculated, and excessive rather than constrained. Brooke-Rose suggests Danielewski parodies both types of present tense and thus might (or might not) bring about a 'sad' end to the possibilities opened up by Robbe-Grillet. ${ }^{48}$ The chapter ends with the sense that it is impossible for a critic to predict what the future will and will not value, and the critical work with which it closes (an interview with Lorna Sage follows) begins with a questioning of the (perceived) value of criticism.

At the end of the chapter 'Splitcrit' in Invisible Author Brooke-Rose argues that in order to be relevant and to engage a readership criticism needs

to reunify all the many now scattered ways of enthusing... and transmitting that enthusiasm without ... summary, ideology, a rigidly held theory, or imposition of abstract structures that have only a limited relevance to any text, [instead] using a sort of ... magpie criticism, that uses the best of past isms without fear of unfashion, and this or that theory if it can enhance understanding, but above all, genuine enjoyment, insight, imagination, a "gift outright" of ourselves, and the compliment of careful reading....49

In short, Brooke-Rose argues for more creative criticism engaged with the text. Novelist and critic come together uniquely in Brooke-Rose, joined at the margins of both fields, where criticism becomes poetic and poetics engage with theory.

\section{Confronting Binaries in Criticism and Theory}

In many ways the plea articulated above is implicit in Thru, a university-set novel full of theory in which fiction is not simply subjected to critical theory but theory is subjected to fiction, and which resists all of the critical limitations outlined above. In 
order to exemplify this point, I will show how Thru engages in criticism by playfully including it in the fiction. The complexity of the text, as we have seen above, is such that the various commentators on Thru employ many of its multiple theoretical intertexts, but usually limit themselves to a couple, for example, Hanjo Berressem concentrates on Lacan and Greimas and Sarah Birch on Kristeva and Irigaray. ${ }^{50}$ Derrida is usually accorded some mention, but the details of his particular influence are not pursued. With a view to showing how useful Thru can be to us as we gaze in retrospect at postmodernism and post-structuralism I will briefly pursue an aspect of that Derridean influence here, focusing on Dissemination, published in France in 1972.

Brooke-Rose herself admitted that she thought Thru 'a very Derridean book' ${ }^{51}$ The translation of deconstruction in Thru emerges in numerous ways. The ' $\mathrm{X}$ ' device, as in Greimas's use as a diagram of contraries and contradictories, could be a shorthand structural plan of Thru (see p. 20) but this is also a significant reference to the chiasmus we find in Derrida is his bracketed note appendant to the Greek X: 'which can be considered a quick thematic diagram of dissemination'. ${ }^{52}$ With this mark as a structural principle it becomes clear Thru is in some measure a deconstructionist novel.

However, this does not mean that Thru ultimately treats Derrida uncritically. While the novel has been written contemporaneously with and in close proximity to the development of poststructuralist thought it is not, as some reviewers believed, merely a vehicle for such ideas. For example, through close-reading, we can see Thru picking up on gender-based commentary from some of Derrida's work. Derrida discusses an example of a semantic argument being used against new ideas, taking the instance of a reaction to Freud's application of the term 'hysterical' to male patients: 'How can a man be hysterical? Hysteron (sic) signifies uterus'. ${ }^{53}$ As Brooke-Rose says in Stories, Theories and Things, 'the very word hysteria, from ustera, uterus, womb, is misogynous...' ${ }^{54}$ While Derrida rejects the whole species of the argument on theoretical grounds, we find that Brooke-Rose's earlier response in Thru, is to pick up and play with the term. There is acrostic play with 'the hystery of the eye' on page 6 of Thru, and later a male character says 'Please stop this hysterical rewriting of history' (76). Thru's play links 'history' to 'His-story', both to a transcendental signified and phallocentric history. 
Such awareness of the gendering of arguments will eventually find Derrida's work provocative. The 'dissemination' he introduces is clearly male (in which seed is spread in an anti-Puritan, anti-Platonic, profligate, masturbatory way) ${ }^{55}$ while other metaphors rely on the passivity of the female. We can see this when Derrida talks about the 'virginity of the page' or 'the closed feminine form of the book, protective of the secret of its hymen...' 56 Thus the opening and reading of the book takes on a violent character: 'Perpetual, the rape has always already taken place and will nevertheless never have been perpetrated'. ${ }^{57}$ Thru finds this hard to take, and weaves these elements into its textual play as in the following quotation:

The heroine after all must not be found too soon.... This seems not to apply to the hero apparent who is allowed to dis-chant his chances and enchantments from tale to tale ten a day for a hundred days owing to the double standard or taleological fallacy of felix culpa that the end be balanced by the meanness and the woman is always the end, the matter upon which you write your narcissistic love the virgin page you soil in which you sow your seed (107)

In this quotation we move from narratologist Vladimir Propp to Derrida, with the second-person address giving it an aggressive immediacy that possibly indicates the speaker is female, whether in her own right or as the fictional creation of another character. The phrase 'hero apparent' condenses 'heir apparent' and male narrative hero, i.e. patriarchy and narrative. We might also note the puns on 'tale' and 'tail' in this semantic environment, where 'fallacy' soon conjures up 'phallusy'. ${ }^{58}$ In male-led theory the tale always writes on the page, male dominates female, but Thru is interested in change.

Derrida's list of oppositional qualities or dyads: 'speech/writing, life/death, master/servant, ...soul/body, inside/outside, good/evil, seriousness/play, day/night, sun/moon' does not include man/woman. ${ }^{59}$ Hélène Cixous, arguing versus phallocentrism, suggests that such deconstructive binaries imply 'Superior/Inferior' and she asks why '... all the couples are couples. Does this mean something? Is the fact that logocentrism subjects thought - all of the concepts, the codes, the values to a two-term system, related to "the" couple man/woman?'. ${ }^{60}$ In Stories, Theories and Things Brooke-Rose accepts the importance of confronting such binaries: 
Now deconstruction is ultimately based on polarities, such as speaking/writing, sound/silence, being/no-being, presence/ absence, man/woman, conscious/unconscious, and has shown how in the logophonocentric metaphysics of presence that has ruled us for twenty five centuries the first term is always somehow privileged, even when equilibrium is supposed. Inverting these polarities can have a dizzy effect, and induces fear, resistance. But could not the ultimate effect not be reequilibration $\ldots ?^{61}$

Post-structuralism and literary theory may have succeeded in removing dominance from the first term of the author/reader binary, but it also advances critical dominance. Thru appears at least partly to be upsetting the male/female binary within a literary/ academic context (both as a narrative set in that context and as a textual entry within it). One of the key recurrent phrases in the latter stages of Thru is 'a complete reform of genital organisation’ (102)

'Genital organisation' is a Freudian term, referring to a 'Stage of psychosexual development'. ${ }^{62}$ Thus 'reform of genital organisation' is a pun that links the political call for 'general reorganisation' with a change in sexual hierarchy and 'a complete reform of congenital [i.e. phallocentric] organisation' (105), 'a complete reorganisation of flute playing phallusies' (106) and a 'complete reform of pregenital organisation' (154). While the idea of genital reform conjured up here might be narrowly interpreted by critics as castration, Thru's genital reorganisation does not exclusively mean this. ${ }^{63}$

The linked phrase 'reorganisation of visceral organs' (107) associates it with a characteristic of Larissa whose 'vicious organs' (109), which have been removed at places across the world, include a 'womb totality' (81). This link between castration and other operations is made explicit on page 130, when Larissa tells Armel of the physical demands of her relationship with Stavro: 'We're playing at gods but for all their ludicrous love life they don't have nephrectomies and other ectomies except maybe castration'. In this light, I think it would be difficult to say that genital reorganisation is clearly gendered. 'Castration' is simply shorthand for a type of genital reorganisation which is about de-gendering or hermaphrodisation (at least in literary terms). For example, we read that 'castration is at the basis of this enjoyment, 
Lancelot giving more pleasure to the ladies than any real imparfit brutal knight...He is a phallus detached from the totality [link back to womb] of the text and walking about the world as a hero' (81, my ellipsis). This passage suggests that reequilibration of male and female terms is at least possible in the non-physical world of fiction.

Armel's portrait of Larissa includes 'the man with the blue guitar' as one of her 27 component parts (85) and among the lines of Stevens' poem is: 'I play. But this is what I think'. It seems to me that that is what is going on in Thru: Brooke-Rose's engagement with a species of criticism in poeticised form is much bolder than her actual criticism. ${ }^{64}$ Among the intentions and the effects of the novel is a subversion of male critical dominance and a genuine questioning of gendered criticism. Thru is that miraculous moment where creativity and criticism are one, and it must have been therapeutic even if it was poorly received or understood at the time.

\section{The Finishing Line}

Brooke-Rose's critical output is just as keen as her fiction to remove the beams and planks cluttering the outlook of literary theory, but her analytic mode is always conscious of the potential for motes obscuring her own vision. While she was more than capable of holding her own as a critic, developments in the discipline and her European career placed her in the awkward situation of being potentially her own best subject and - theoretically in the context of Barthes 'Death of the Author' - deceased at the same time. Invisible Author comes from within this bind but has high hopes for the future of criticism when its fashions change.

Making no large claims for my contributions to published material on BrookeRose, I can only be flattered by the time and effort she put into corresponding with me. I was already fascinated by and working on Thru before we interacted, but facing the discipline of making my points plausible to the author herself formed a watershed moment in my intellectual development. I was incredibly fortunate to have the benefit of Christine's candour, honesty and engagement in my enquiries. Nevertheless, I can see how nervous and defensive I was throughout our interactions, caught up -with Christine- in the paradox that the Author's opinions did not count. Ultimately it was the critic that I needed to hear from, rather than the author, or the rider rather than the horse herself. 
The critical race that is being run is long distance, however, and no one can really predict the end, but Brooke-Rose remains highly relevant to criticism as practitioner and subject. This has long been clear to writers on experimental literature who see the close combination of theory and practice; the focus on the 'how' as she put it. In a recent major survey of the field, The Routledge Companion to Experimental Writing, Brooke Rose is a reference point for five contributors, including all three editors in separate essays. One of these is Brian McHale for whom Brooke-Rose's work (most significantly Thru) forms a key coordinate in an attempt to mitigate some of the fractures in postmodern theory. ${ }^{65}$ More recently still, in Simon Barton's Visual Devices in Contemporary Fiction the unconventional pages of Thru are foundational rather than examples of eccentricity or difficulty. ${ }^{66}$ Historical perspective makes these works more, not less, accessible, but possessing a critical axe to grind or an interest in experimentation are not essential to an interest in BrookeRose. Each reader finds their own way in to Brooke-Rose's work (or not), and their own process of discovery is what makes her work special to them. The current volume is evidence of a wider resurgence of interest in Brooke-Rose which indicates that this author is still in the running for deserved and necessary posthumous recognition.

${ }^{1}$ Brooke-Rose, Christine (2002) Invisible Author: Last Essays, Colombus: Ohio State University Press; see also Brooke-Rose (1997) 'Is Self Reflexivity Mere?', Quarterly West Winter 1996-7: 230-265.

2 Letter from the author to Christine Brooke-Rose dated 08/01/98.

3 White, Glyn (2002) "YOU ARE HERE": Reading and Representation in Christine Brooke-Rose's Thru', Poetics Today 23 (4): 611-31; White, Glyn (2005) Reading the Graphic Surface: The Presence of the Book in Prose Fiction, Manchester: Manchester University Press.

${ }^{4}$ Christine Brooke-Rose, Letter to the author dated 04/11/05.

5 Christine Brooke-Rose, Letter to the author postmarked 27/07/98.

${ }^{6}$ Christine Brooke-Rose, Letter to the author dated 04/02/98, p.3.

7 Brooke-Rose, Christine (1975) Thru, London: Hamish Hamilton. Page references to this novel will be given in the text. It is currently available in The Christine Brooke Rose Omnibus Four Novels: Out, Such, Between, Thru, (1986) Manchester: Carcanet and to find the relevant pages in this edition the reader will have to add the 578 pages of the three preceding novels.

${ }^{8}$ Levitt, Morton P. (1985) 'Christine Brooke-Rose' in The Dictionary of Literary Biography: British Novelists since 1960 14: 124-9, p.126; McHale, Brian (1987)

Postmodernist Fiction, New York: Methuen, p.185.

${ }^{9}$ Reyes, Heather (1998) 'Delectable Metarealism/ Ethical Experiments; re-reading Christine Brooke-Rose', PhD thesis, Birkbeck, London. See White 2005: 124-6. 
${ }^{10}$ Christine Brooke-Rose, Letter to the author dated 04/02/98, p.4.

11 Grant, Damien (1995) 'The Emperor's New Clothes: Narrative Anxiety in Thru' in Friedman, Ellen J. \& Martin, Richard (eds), Utterly Other Discourse, Normal,

Illinois: Dalkey Archive: 117-129 discussed in Brooke-Rose (2002) pp.183-4; Martin, Richard (1995) 'Stepping Stones in the Dark: Redundancy and Generation in Amalgamemnon' in Friedman, Ellen J. \& Martin, Richard (eds), Utterly Other Discourse, Normal, Illinois: Dalkey Archive: 143-152, discussed in Brooke-Rose (2002) pp.30-2.

12 Christine Brooke-Rose, Letter to the author dated 04/02/98, p.3.

${ }^{13}$ Christine Brooke-Rose, Letter to the author dated 04/02/98, p.4.

14 McHale, Brian (1987) p.252. My ellipsis.

15 Brooke-Rose, Christine, letter to the author dated 04/02/98, p.5.

16 Brooke-Rose, Christine (1991) Stories, Theories and Things, Cambridge:

Cambridge University Press, p.237.

17 Little, Judy (1996) The Experimental Self: Dialogic Subjectivity in Woolf, Pym, and Brooke-Rose, Carbondale: Southern Illinois University Press, p.1.

18 See White 2005: 149-53.

19 Cohen, Keith \& Hayman, David (1976) 'An Interview with Christine BrookeRose', Contemporary Literature 17: 1-23, p.11.

${ }^{20}$ Brooke-Rose (1991) p.15.

21 Brooke-Rose, Christine, letter to the author dated 04/02/98, p.4.

22 Brooke-Rose, Christine, letter to the author dated 25/02/98, p.1.

${ }^{23}$ Eco, Umberto (1992) Interpretation and Overinterpretation, Stefan Collini (ed.), Cambridge: Cambridge University press; Brooke-Rose 2002, see especially p.31.

24 Brooke-Rose, Christine, letter to the author dated 25/02/98, p.1.

25 Brooke-Rose, Christine, letter to the author dated 25/02/98, p.1.

26 Matthew 7: 24-7.

27 McHale, Brian (1995) " II draw the line as a rule between one solar system and another": The Postmodernism(s) of Christine Brooke-Rose' in Friedman, Ellen J. \& Martin, Richard (eds), Utterly Other Discourse, Normal, Illinois: Dalkey Archive: 192-213, p.200, my ellipsis.

28 White (2002) p.626.

29 McHale (1995) 200.

30 Matthew 7: 3.

31 See Brooke-Rose (2002) p.76.

32 Matthew 7: 1-2.

33 Stevens, Wallace (1965) Selected Poems, London: Faber, pp.52-74.

34 Brooke-Rose (1991) p.206.

35 Currie, Mark (1998) Postmodern Narrative Theory, London: Palgrave, p. 64.

36 Christine Brooke-Rose, letter to the author, dated 28/02/98, p.1.

37 Christine Brooke-Rose, letter to the author, dated 28/02/98, p.1.

${ }^{38}$ Christine Brooke-Rose, letter to the author, dated 28/02/98, p.1.

39 See White (2005) p.136.

40 Brooke-Rose (2002) p.17.

41 Brooke-Rose (2002) p.107.

42 Brooke-Rose (2002) p. 15.

43 Brooke-Rose (2002) p.7.

${ }_{4}$ Brooke-Rose (2002) p.2.

45 E-mail correspondence from Christine Brooke-Rose 06/03/2003. 
46 Brooke-Rose (2002) p.5, my ellipsis.

${ }^{47}$ Danielewski, Mark Z (2000) House of Leaves, London: Anchor (2 ${ }^{\text {nd }}$ ed.) pp.26-7.

48 Brooke-Rose (2002) p.168.

49 Brooke-Rose (2002) p.35, my ellipses.

50 Berressem, Hanjo (1995) 'Thru the Looking Glass: A Journey into the Universe of Discourse', Utterly Other Discourse, in Friedman, Ellen J. \& Martin, Richard (eds), pp.104-116; Birch, Sarah (1994) Christine Brooke-Rose and Contemporary Fiction, Oxford: Clarendon; Maack, Annagret (1995) 'Narrative Techniques in Thru and Amalgamemnon' in Friedman, Ellen J. \& Martin, Richard (eds), Utterly Other Discourse, Normal, Illinois: Dalkey Archive: 130-142.

51 Friedman, Ellen J. and Fuchs, Miriam (1995) 'A conversation with Christine Brooke-Rose' in Friedman, Ellen J. \& Martin, Richard (eds), Utterly Other Discourse, Normal, Illinois: Dalkey Archive: 29-37, p.36.

52 Derrida, Jacques (1981) Dissemination, Chicago: University of Chicago Press (translated by Barbara Johnson), p.44.

${ }^{53}$ Derrida (1981) footnote on p.182.

${ }^{54}$ Brooke-Rose (1991) p. 241.

55 Derrida (1981) pp. 149-54, 304.

56 Derrida (1981) p.239.

57 Derrida (1981) p.260.

58 See Thru pp.112, 109, 106.

59 Derrida (1981) p.85.

60 Cixous, Hélène (1988) 'Sorties', Modern Criticism and Theory (D. Lodge ed.), London: Longman, pp.287-93, p. 287.

61 Brooke-Rose (1991) p.178, my ellipsis.

${ }^{62}$ Laplanche, J. \& Pontalis, J.B. (1988) The Language of Psychoanalysis, London:

Karnac, p.102.

${ }^{63}$ See Cohen and Hayman (1986) pp. 11-12.

${ }^{64}$ Compare Brooke-Rose (2002) p.157.

65 Bray, Joe, Gibbons, Alison and McHale, Brian (eds) (2012) The Routledge

Companion to Experimental Writing, Abingdon: Routledge.

66 Barton, Simon (2106) Visual Devices in Contemporary Prose Fiction, Houndmills: Palgrave, pp.82-6. 